\title{
First record of Homalocephala biumbrata (Wahlberg, 1839) from Bohemia (Czech Republic), with notes on adult behaviour (Diptera: Ulidiidae)
}

\author{
Jindřich Roháček \& Petr Bílek
}

\begin{abstract}
First record of Homalocephala biumbrata (Wahlberg, 1839) from Bohemia (Czech Republic), with notes on adult behaviour (Diptera: Ulidiidae). - Čas. Slez. Muz. Opava (A), 60: 193-198, 2011.

Abstract: Homalocephala biumbrata (Wahlberg, 1839) (Ulidiidae) is a new addition to the fauna of Bohemia, based on records from the locality Na Plachtě reserve nr. Hradec Králové (E. Bohemia, Czech Republic). New biological and distributional data about this species are provided together with description of adult courtship behaviour (documented by photography). The importance of this record is discussed.
\end{abstract}

Keywords: Diptera, Ulidiidae, Homalocephala biumbrata, new record, biology, Czech Republic (Bohemia), distribution, adult behaviour

\section{Introduction}

Representatives of the genus Homalocephala Zetterstedt, 1838 (Diptera: Ulidiidae) are infrequently encountered in Central Europe. The genus has a predominatly northern distribution: all six species recorded from Europe are known from Scandinavia (cf. Andersson 1991; Kameneva 2008; Kameneva \& Greve 2011) while only four of them have also been found in (usually montane) areas of Central Europe (Merz \& Roháček 2005; Kameneva 2008; Kameneva \& Greve 2011). However, the occurrence of most of Central European Homalocephala species is based on old records; actually, the only really recent findings are those of H. biumbrata (Wahlberg, 1839) from France, Czech Republic (Moravia only) (Merz \& Roháček 2005), Slovakia (Roháček \& Heřman 2009) and Ukraine (Kameneva 2002, 2008).

The biology of Homalocephala species is insufficienctly known. They seem to be associated with fallen trunks of either deciduous or coniferous trees. Adults can be seen running on sunlit parts of the logs. As far as is known, larvae develop under bark, rarely in sap runs or in decayed leaves (Zetterstedt 1838; Wahlberg 1839; Steyskal 1965; Allen \& Foote 1967; Cogan \& Dear 1974; Perry \& Stubbs 1978; Lukasheva 1987; Krivosheina \& Krivosheina 1995; Perry \& Rotheray 2010) but preimaginal stages hitherto remain undescribed in this genus.

From the Czech Republic only Homalocephala biumbrata (Wahlberg, 1839) has been reported (Roháček 2009), based on two Moravian records, one from the Hrubý Jeseník Mts. (Velká kotlina glacial cirque), the other from the Moravskoslezské Beskydy Mts. (Lysá hora Mt.), see Merz \& Roháček (2005).

\section{Material and methods}

All the material examined is deposited in the collection of Silesian Museum (Opava, Czech Republic). The only female from E. Bohemia was captured by the junior author (PB) directly on the tree trunk in a plastic vial and subsequently preserved in $70 \%$ ethanol. Label data are presented in full including habitat and other biological information. Habitat, tree trunk and other (observed) specimens of Homalocephala biumbrata were documented by photography (P. Bílek). All images were photographed using a digital camera Canon EOS 40D with macrolenses Canon EF 100mm 1:2,8 USM.

\section{Study area}

The locality $\mathrm{Na}$ Plachtě (Nature Reserve) is situated at the SE margin of the town Hradec Králové (E. Bohemia, Czech Republic). It covers an area of 30.3 ha and lies in the quadrant 5861a (according to Central European grid mapping). Since 1897 the major part of the locality has been serving as a military training area. 
Due to the military activities and extensive sand excavation various periodical or permanent smaller water bodies were formed in field depression in addition to two ponds (named Jáma and Plachta) which were already established in the area in 15th century. Geomorphologically this protected area belongs to the Eastern Bohemia Plateau, the unit Eastern-Elbe Plateau, the Pardubice Depression and its average altitude is $240 \mathrm{~m}$. The underlying geology of the area is formed of the Upper Turonian and Coniacian marlite and calcareous claystone out-capping. These layers are covered with gravel-sand terraces of the River Orlice. The climate of the locality is characterised by long, warm and dry summers, short, moderately warm and dry winters with a short snow cover, and a yearly average temperature of $8.5^{\circ} \mathrm{C}$ and cca $600 \mathrm{~mm}$ precipitation. The area belongs to the Bohemian Thermophyticum and falls under hill country belt. Its rich flora is composed of species of the temperate-Central European and European zone but the occurrence of atlantic, subthermophilous, submontane to montane species are also represented in a rich mosaic of heterogenous plant communities. Most of the area is deforested, formed of sandy places, various grassland and heatland habitats but also wetland habitats (marsh of alders, fens, wet meadows, wet heaths) along with ponds and pools which have become partly overgrown by self-seeding woody plants (birches, aspens, willows, pines). The heterogenous mosaic of microclimatically different habitats has resulted in a very large biodiversity in the area, both as to flora and fauna (for more detail see Mocek 1997a and other articles in the proceedings devoted to the Na Plachtě locality, see Acta Musei Reginaehradecensis, Ser. A., Vol. 25, 1997, 238 pp.). A review of the fauna of selected families of Diptera in this locality was given by Mocek (1997c).

\section{Homalocephala biumbrata (Wahlberg, 1839)}

(Figs 1-3, 5, 6)

Material examined: CZECH REPUBLIC: E. Bohemia: Na Plachtě reserve nr. Nový Hradec Králové, $50^{\circ} 11^{\prime} 14.29^{\prime \prime} \mathrm{N}, 15^{\circ} 51^{\prime} 26.54^{\prime \prime E}, 244 \mathrm{~m}$, on dead fallen aspen (Populus tremula) trunk, 22.ix.2011, 1ठ1우, P. Bílek observed and photographed; 1 ㅇ (of the above pair) captured 26.ix.2011, P. Bílek leg.; N. Moravia: Hrubý Jeseník Mts, Velká kotlina glacial cirque, $50^{\circ} 03^{\prime} 11^{\prime \prime N}, 17^{\circ} 14^{\prime} 39^{\prime \prime E}$, 1123 m, Malaise trap, 9.vi.-26.vi.2006, $1{ }^{\widehat{\lambda}} 1$ 우, J. Roháček J. \& Ševčík leg., all J. Roháček det., all in coll. Silesian Museum, Opava (dried from ethanol, mounted on pinned triangular cards).

Distribution: This Holarctic species (cf. Krivosheina \& Krivosheina 1995; Kameneva 2001, 2008) is widespread in Northern Europe and Great Britain, but has been rarely recorded from Central and Western Europe, viz. from France, Germany, Austria, Italy, Czech Republic, Slovakia and Ukraine (Kameneva 2002; Merz \& Roháček 2005; Roháček \& Heřman 2009; Kameneva \& Greve 2011). Its only records from the Czech Republic (Moravia only, an additional record is listed above) originate from high altitudes in the Hrubý Jeseník Mts (1123-1150 m) and Beskydy Mts (1323 m), see Merz \& Roháček (2005) and material examined. The above record is the first from Bohemia and is interesting for its low altitude (only $244 \mathrm{~m}$ ) because the other known Central European records are from much higher altitudes (only that by Roháček \& Heřman 2009 is from about $560 \mathrm{~m}$ ) and the species is hence considered to be of boreo-montane distribution.

Biology: Wahlberg (1839) noted the occurrence of larvae of this species in rotten leaves (cf. also Andersson 1991) but according to Krivosheina \& Krivosheina (1995) the species develops under bark of fallen trunks of aspen, poplar or willow; larvae occur in wet bast on lower side of the trunk, usually in groups of 25-30 specimens, feed on liquid exudates from bast filaments and pupate inside the bast; adults emerge in June-September. Kameneva (2002) recorded adults from a poplar (Populus nigra) trunk in Ukraine, Merz \& Roháček (2005) from the cut end of a tree stump in France and Roháček \& Heřman (2009) from a cut (but relatively fresh) log of aspen in Slovakia; also Perry \& Rotheray (2010) listed this species as associated with aspen in Scotland. The above finding in the $\mathrm{Na}$ Plachtě reserve again showed the affinity of adults to cut aspen logs (Fig. 4); thus, the dead aspen or poplar trunks seem to be particularly attractive for imagoes of $H$. biumbrata. In this locality the aspen trunk was situated outside the forest (Fig. 8), at the margin of a path running through a xerophilous meadow (with heathland and some pools in the vicinity). The margins of the path are bushy with some trees: predominantly Salix caprea and Populus tremula, less often Betula verrucosa and Pinus silvestris. This situation closely resembles that in the Hriňová-Dolná 

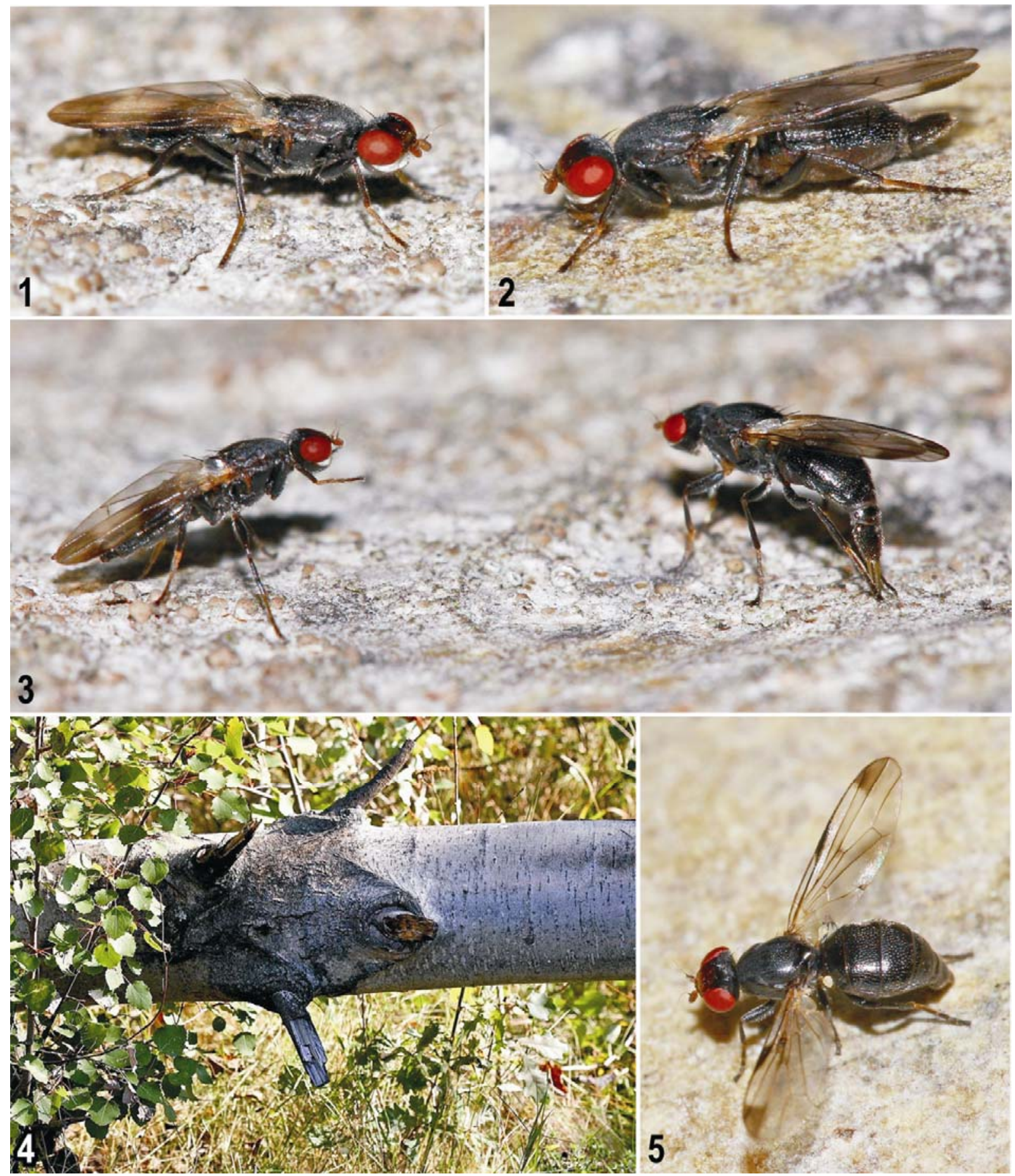

Figs 1-5: Homalocephala biumbrata (Wahlberg) and its habitat. 1 - male; 2 - female; 3 - a pair during courtship behaviour on aspen bark; 4 - detail of cut aspen (Populus tremula) trunk where Homalocephala specimens occurred; 5 - female waving with wings. All photos by P. Bílek.

Riečka (Pol’ana Mts, C. Slovakia - Roháček \& Heřman 2009) where the species was also collected on a cut aspen log at the margin of a field path on dry sloping meadow. In the $\mathrm{Na}$ Plachtě reserve H. biumbrata occurred on the trunk together with Strongylophthalmyia ustulata (Zetterstedt, 1847) (Strongylophthalmyiidae, see Fig. 7), an unidentified species of Pallopteridae and a specimen of Medetera sp. (Dolichopodidae) while in Dolná Riečka it was found in company with a number of Megamerina dolium (Fabricius, 1805) (Megamerinidae) and single specimens of Rainieria calceata (Fallén, 1820) (Micropezidae), Lonchaea fugax 
Becker, 1895 and L. patens Collin 1953 (Lonchaeidae). However, these two samples markedly differ in the date (22.-26.ix and 4.vii. respectively). Based on literary records and material examined adults of $H$. biumbrata occur in June-September and the record from $\mathrm{Na}$ Plachtě res. is apparently the latest known (26.ix.).

Adult behaviour: During photography of the flies a peculiar behaviour of a pair (the male in particular) of H. biumbrata was observed by the junior author on September 22nd, 2011. The male, when it saw the female, at first crawled (creeping low on the bark) towards the female which was standing with its ovipositor well extended and touching the surface of the bark (see Fig. 3). Subsequently the male raised its fore body and fenced (gesticulated) with its fore legs (cf. Fig. 3) and then suddenly began to move extremely rapidly from left to right (Fig. 1) but continued to face the female which only waved alternately with its wings (Fig. 5) as is usual in most Ulidiidae and related families with patterned wings. The female then interrupted its wing waving for a short period and again exposed its ovipositor perpendicularly to surface of the bark (Fig. 3). Despite the vigorous male courtship behaviour no attempt at mating was observed and, therefore, it appears that the posture of the female with its ovipositor touching the bark signaled to the male its rejection of copulation. Interestingly, this female (easily recognizable by a defect in the venation on its left wing) was found and captured on the same aspen trunk 4 days later (on September 26th).

\section{Discussion}

The record of Homalocephala biumbrata from E. Bohemia is not only important faunistically but also as regards new biological and ethological (adult courtship behaviour) information, see above. In addition, the list of the dipterous fauna of the Na Plachter reserve (see Mocek 1997c) is enriched by two species that are rare in Central Europe, viz. $H$. biumbrata and Strongylophthalmyia ustulata, both associated with fallen trunks of dead trees. The occurrence of the Boreo-montane H. biumbrata in this locality is particularly interesting and it, together with other montane elements already known from this locality (cf. Mocek 1997b - Odonata, Mikát et al. 1997 - Coleoptera), demonstrate that cold-loving (montane, Boreo-montane etc.) species can survive here in suitable microhabitats at unexpectedly low altitudes (235-246 m).

Acknowledgements: We should like to thank to C. Martin Drake (Axminster, England, U. K.) for his kind improvement of the English of this paper and to Elena P. Kameneva (Kiev, Ukraine) for valuable comments and unpublished information. The study was partly supported by grant IGS201103 of the Slezské zemské muzeum (J. Roháček).

\section{References}

Allen E. J. \& Foote B. A. (1967): Biology and immature stages of three species of Otitidae (Diptera) which have saprophagous larvae. - Annls Entomol. Soc. Am., 60: 826-836.

Andersson H. (1991): Revision of Swedish Homalocephala Zetterstedt (Diptera, Otitidae). - Entomol. Tidskr., 112: 27-32.

Cogan B. H. \& Dear J. P. (1974): Additions and corrections to the list of British Acalyptratae Diptera. Entomol. Month. Mag. 110: 173-181.

Kameneva E. P. (2001): 76-77. Ulidiidae (Otitidae, Pterocallidae, Ortalidae) - Lentokrylki. Pp. 157-165. In Lehr P. A. (ed.): Opredelitel' nasekomykh Dal'nego Vostoka Rossii v shesti tomakh [Key to insects of Russian Far East in six volumes]. Vol. 6, Pt. 2, Dal'nauka, Vladivostok, 641 pp.

- (2002): The first record of the genus Homalocephala (Diptera, Ulidiidae) in Ukraine. - Vestnik Zool. 36(3): 14.

- (2008): New and Little-Known Ulidiidae (Diptera, Tephritoidea) from Europe. - Vestnik Zool. 42(5): 427454.

Kameneva E. P. \& Greve-Jensen L. (2011): Ulidiidae. In Pape T. \& Beuk P. (eds): Fauna Europaea: Diptera, Brachycera. Fauna Europaea, version 2.4, http://www.faunaeur.org. 

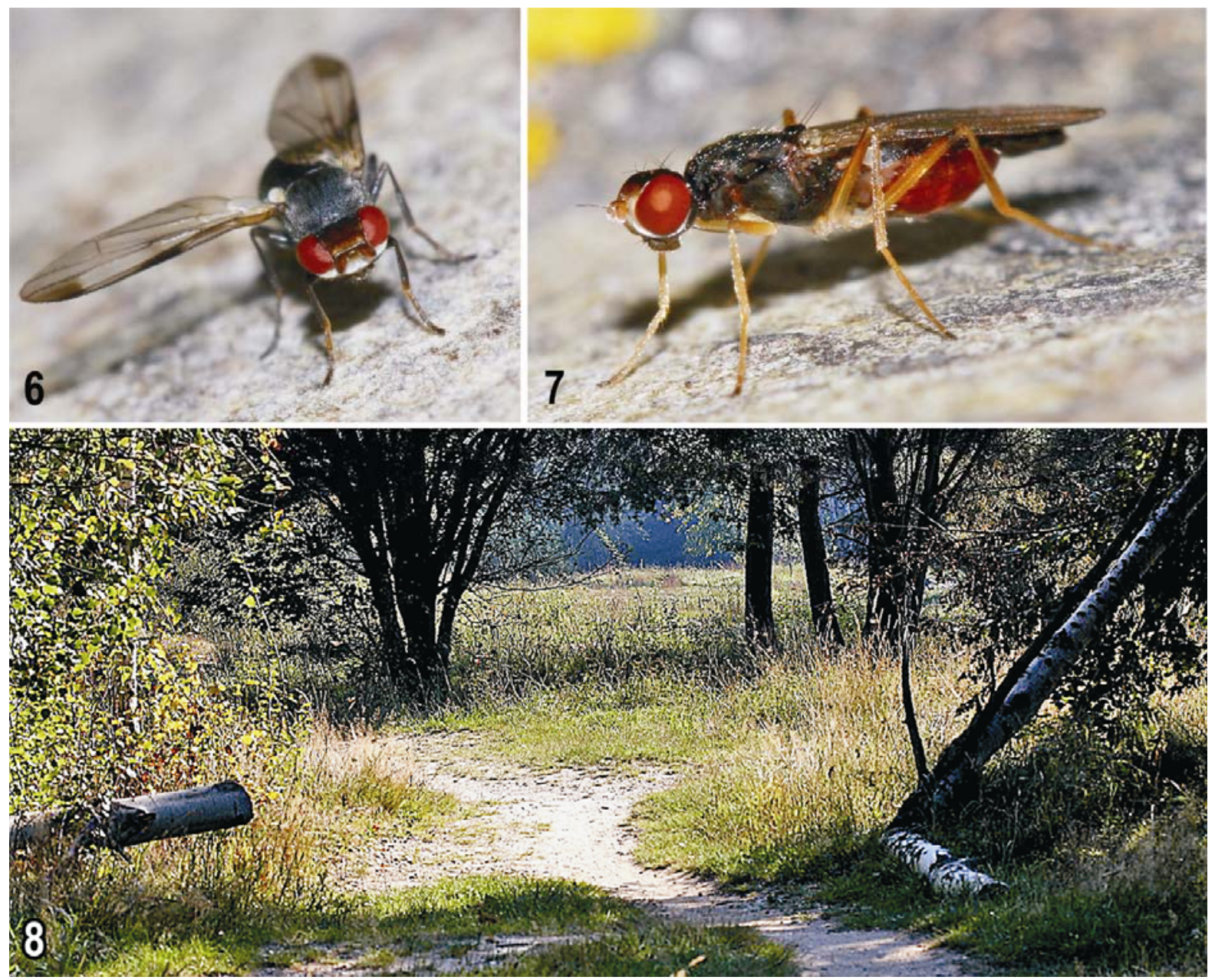

Figs 6-8: 6 - Homalocephala biumbrata, male (frontal view); 7 - Strongylophthalmyia ustulata (Zetterstedt), female on aspen bark. 8 - habitat of both species in the Na Plachtě reserve with cut aspen log on the left. All photos by P. Bílek.

Krivosheina M. G. \& Krivosheina N. P. (1995): A revision of the genus Homalocephala Zetterstedt, 1838 (Diptera Ulidiidae) of Russia. - Russian Entomol. J., 4: 109-113.

Lukasheva N. V. (1987): Ksilofil'nye dvukrylye severo-zapadnogo Kavkaza. [Xylophylous Diptera of the north-west Caucasus]. Zoologicheskij institut AN SSSR, Leningrad, 143 pp. (in Russian).

Merz B. \& Roháček J. (2005): New records of Homalocephala biumbrata (Wahlberg, 1839) (Diptera, Ulidiidae, Ulidiinae) from Western and Central Europe. - Studia dipterologica 12: 8-9.

Mocek B. (1997a): Výsledky přírodovědných výzkumů lokality Hradec Králové - „Na Plachtě“ ve východních Čechách. Results of the botanical and zoological researchs in the locality Hradec Králové - „Na Plachtě“ (Eastern Bohemia, Czech Republic). - Acta Mus. Reginaehradecensis (A), 25: 3-20.

- (1997b): Fauna vážek (Odonata) lokality Hradec Králové - „Na Plachtě“ (východní Čechy, Česká republika). Dragonflies (Odonata) in the locality Hradec Králové - „Na Plachtě“ (Eastern Bohemia, Czech Republic). Acta Mus. Reginaehradecensis (A), 25: 79-88.

- (1997c): Přehled druhů některých čeledí dvoukřídlých (Diptera) zjištěných na lokalitě „Na Plachtě“ (východní Čechy, Česká republika). Survey of species of some families of Diptera in the locality „Na Plachtě“ (Eastern Bohemia, Czech Republic). - Acta Mus. Reginaehradecensis (A), 25: 197-205.

Perry I. \& Rotheray G. E. (2010): Chapter 3. Immature stages of flies and some microhabitats. Dead wood and sap runs. Pp. 144-157. In Chandler P. (ed.): A dipterist's handbook (2nd Edition). The Amateur Entomologist Vol. 15, The Amateur Entomologist's Society, Brentwood, Essex, 525 pp.

Perry I. \& Stubbs A. E. (1978): Chapter 3. Some micro-habitats. Dead wood and sap runs. Pp. 65-73. In Stubbs A. \& Chandler P. (eds): A dipterist's handbook. The Amateur Entomologist, Vol. 15, The Amateur Entomologist's Society, Hanworth, Middlesex, 255 pp.

Roháček J. (2009): Ulidiidae Macquart, 1835. In Jedlička L., Kúdela M. \& Stloukalová V. (eds): Checklist of Diptera of the Czech Republic and Slovakia. Electronic version 2. $<$ http://zoology.fns.uniba.sk/diptera2009> + CD-ROM: ISBN 978-80-969629-4-5. 
Roháček J. \& Heřman P. (2009): Ulidiidae. Pp. 195-197. In Roháček J. \& Ševčík J. (eds): Diptera of the Pol'ana Protected Landscape Area - Biosphere Reserve (Central Slovakia). SNC SR, Administration of the PLA - BR Pol'ana, Zvolen, 340 pp.

Steyskal G. C. (1965): Otitidae. Pp. 642-654. In Stone A.., Sabrosky C. W., Wirth W. W., Foote R. H. \& Coulson J. R. (eds): A catalog of the Diptera of America north of Mexico. U.S. Department of Agriculture Handbook 276, Washington, 1696 pp.

Wahlberg P. F. (1839): Bidrag till svenska dipternas kännedom. - Kongl. Vetensk. Acad. Handl., 1838: 1-23.

Zetterstedt J. W. (1838). Dipterologis Scandinaviae. Sect. 3: Diptera. Insecta Lapponica, L. Voss, Lipsiae [= Leipzig], 477-868 pp.

\section{První nález doličnatky Homalocephala biumbrata (Wahlberg, 1839 v Čechách (Česká republika), s poz- námkami k chování imág (Diptera: Ulidiidae)}

Př́íspěvek uvádí první český nález doličnatky Homalocephala biumbrata (Wahlberg, 1839) (Ulidiidae), učiněný v rezervaci $\mathrm{Na}$ Plachtě u Hradce Králové (kvadrant sít'ového mapování 5861a) a prezentuje nové bionomické a etologické informace o tomto vzácném druhu, získané při jeho pozorování a fotografování. Tento boreomontánní druh zde byl nalezen v mimořádně nízké nadmořské výšce (pouze $244 \mathrm{~m}$ ), s dosud nejpozdějším datem výskytu (26.ix.) a poprvé bylo pozorováno jeho předkopulační chování (dvoření), viz. Figs 1-3, 5. Vedle tohoto druhu byla fauna rezervace $\mathrm{Na}$ Plachtě obohacena ještě o nález dalšího saproxylického druhu Strongylophthalmyia ustulata (Zetterstedt, 1847) z čeledi Strongylophtalmyiidae (Fig. 7), který se vyskytoval na stejnem kmeni pokácené osiky (Figs 4,8 ) jako pár doličnatky H. biumbrata.

Authors' addresses: Jindřich Roháček, Slezské zemské muzeum, Tyršova 1, CZ - 74646 Opava, Czech Republic; e-mail: rohacek@szmo.cz Petr Bílek, Selicharova 1286, CZ - 50012 Hradec Králové 12, e-mail: petmichbil@email.cz 